\title{
Investigation of the patients' perception on dental treatment and their anxiety levels during the COVID-19 pandemic process
}

\author{
(1)İrem Karagözoğlu, @Özge Parlar Öz \\ University of Gaziantep, Faculty of Dentistry, Department of Prosthodontics, Gaziantep, Turkey
}

Cite this article as: Karagözoğlu İ, Parlar Öz Ö. Investigation of the patients' perception on dental treatment and their anxiety levels during the COVID-19 pandemic process. J Health Sci Med 2021; 4(5): 710-715.

\begin{abstract}
Aim: The objectives of this study are to evaluate the anxiety levels of patients toward dental treatment during the pandemic process, to obtain information about the level of awareness, perceptions and attitudes of patients seeking dental treatment and to determine the relationship between anxiety levels and socio-demographic variables of individuals.

Material and Method: A total of 300 patients who applied to the dentistry faculty were included in the study, and a survey questionnaire was administered to these patients. The survey consisted of three parts; in the first part, the socio-demographic features of the patients were asked, in the second, the State-Trait Anxiety Inventory (STAI) developed by Spielberger was used to measure the level of anxiety, and in the last part, a questionnaire form about the perceived sensitivity to COVID-19 developed by the authors was applied. The statistical analysis of the data was performed with SPSS for Windows version 24.0 and a p value less than 0.05 was accepted as statistically significant. The normality of distribution of continuous variables was tested by the Shaphiro-Wilk test. The Mann Whitney U, Kruskal-Wallis and Dunn multiple comparison tests were used to compare non-normal data between two or more groups.
\end{abstract}

Results: A total of 300 patients, 155 men and 145 women, participated in the study. The mean state anxiety score was $43.38 \pm 8.34$. Significant differences were not found among the independent variables affecting the level of anxiety, age, gender, marital status, education, whether individuals have had COVID-19. When the questions evaluating the patients' perception on dental treatment were compared with the anxiety scores, there were statistically significant differences among groups.

Conclusion: The study results revealed that the patients had a high level of anxiety in places such as dental hospitals where many patients are treated, but they were aware of the preventive measures to be taken during the pandemic process.

Keywords: COVID-19, dental treatment, anxiety

\section{INTRODUCTION}

COVID-19 is a viral infection caused by the new type of corona virus that emerged in Wuhan, China, in 2019. The disease then spread to the rest of Asia, Europe, America and the whole world and was declared as a "pandemic" by the World Health Organization (WHO) on March 11, 2020. COVID-19 is highly contagious and transmitted directly through coughing, sneezing or indirectly through personto-person contact and saliva. It has also been reported that the COVID-19 virus can be transmitted by aerosols formed during medical and dental procedures (1). There is a high risk of cross infection between dentists and patients in dental clinics and hospitals. Since dentists work in close proximity with patients, they are at particularly high risk of being infected by, as well as transmitting COVID-19

to, their patients (2). In order to prevent the spread of the disease, individuals are constantly informed about wearing masks, maintaining social distance, and complying with hygiene rules. However, achieving success in the pandemic process depends on the awareness and attitude of the individuals. At the onset of the pandemic, only emergency dental treatments were allowed in many countries, in line with the recommendations of National Dental Councils. However, with the normalization, when dentists take all protective measures, they can also perform routine dental treatments (3). Various protective precautions are taken especially in dentistry faculties or hospitals where many patients are treated. These precautions include the use of protective equipment, deep ventilation filtering, 
increased attention to complying with personal hygiene behaviors, ensuring social distance among patients and vaccination of doctors and healthcare professionals in the hospital. Dentists started to treat patients by taking all necessarry precautions, but the thought that there is a risk of contamination while receiving dental treatment in patients continues. Especially in dentistry faculties or hospitals, patients avoid seeking dental treatment.

Another problem seen in the pandemic process is psychological health of individuals. The pandemic has brought some concerns and anxiety in people. The anxiety is defined as extensive emotional reaction emerging against dangerous situations or events, aimed at adapting to current conditions (4). Two types of anxiety are defined as "state anxiety" and "trait anxiety". State anxiety is defined as a temporary emotional state characterized by subjective feelings of tension and fear. Trait anxiety, on the other hand, shows the anxiety tendency that exists in the individual relatively, and it is the state of intensification and continuity of state anxiety $(4,5)$. Various scales have been developed to measure anxiety in people. The State-Trait Anxiety Inventory (STAI) was developed by Speilberger et al. to measure state and trait anxiety (5).

During the pandemic process, some people developed psychological problems due to the quarantine, while some others experienced high anxiety. Despite the great importance given to the measures taken regarding the pandemic, determining the mental health of people affected by the pandemic has been relatively neglected. Being aware of the anxiety and perception of individuals that may arise during the pandemic is important in terms of the spread and control of the disease. There are many studies in the literature examining the anxiety levels of dentists against COVID-19, and most of them have shown that treating patients with protective equipment is not seen as a problem for dentists $(2,3,14)$. However, studies conducted with patients are not sufficient, thus one of the aims of this study is to measure the state anxiety levels of patients who apply for dental treatment. Compared to period when the pandemic first started, many patients, felt safe in the face of the measures taken and began to receive dental treatment. Another purpose of the study is to determine how the protective measures taken were perceived by patients and their reactions against protective measures while being treated. For these purposes, the following questions were answered in this study:

- Is there a significant difference between the state anxiety levels and socio-demographic characteristics of the participants?

- Is there a significant difference between the state anxiety levels of paticipants and patient-related questions?

\section{MATERIAL AND METHOD}

The survey was approved by the Gaziantep University Clinical Researchs Ethics Committee (Date: 10.03.2021, Decision No: 2021/68). All procedures were carried out in accordance with the ethical rules and the principles of the Declaration of Helsinki.

Since the number of individuals in the target audience was unknown, the total sample size was determined based on the percentage measurement values of the studies and calculated using the G-Power software with a confidence interval of $95 \%$ and a margin of error of $5 \%$.

The cross-sectional study was conducted with 300 patients receiving dental treatment in the dentistry faculty of Gaziantep University. All the patients invited responded to the survey (100\%). An interview survey was designed to collect the data and administered by two dentists. The survey consisted of three parts; in the first part socio-demographic variables of participants such as gender, age, education, marital status and if she/he had COVID-19 before were asked. The second part includes COVID-19 and patient-related questions prepared by two dentists. In the last part, Spielberger's STAI-S (state) anxiety scales were administered to the patients.

The anxiety level was measured using the State-Trait Anxiety Inventor developed by Spielberger et al., that consists of 40 items and two sub-inventories measuring the state and trait anxiety levels (5). The adaptation of the inventory to Turkish and validity-reliability study of the Turkish version were carried out by Oner and Le Compte (6). In this study, only the State Anxiety subscale was used. The reason for this is that the State Anxiety Scale describes how the individual feels at a certain time and under stressful conditions and includes the response by taking into account individuals' feelings about the current situation. The state Anxiety Scale consists of 20 items in total. There is no time limit for answering the scale consisting of short statements. Emotions or behaviors expressed in the items of State Anxiety Scale are answered by marking one of the options as (1) none, (2) some, (3) much, (4) completely, according to their severity. There are two types of expressions in the scale as called direct/straight and inverted expressions. Direct statements express negative emotions, while inverted statements express positive feelings. Answers with a value of 4 in direct expressions indicate that the anxiety is high. On the other hand, in inverted expressions, answers with a value of 1 refer high anxiety, a score of 4 indicates low anxiety.

The SPSS 24.0 software for windows was used for the statistical analysis of the data. While evaluating the study data, in addition to using descriptive statistical methods (mean, standard deviation, median, frequency, ratio, 
minimum, maximum), the conformity of the data to normal distribution was checked with the Shaphiro-Wilk test. The Mann-Whitney U, Kruskal Wallis and Dunn multiple comparison tests were used to compare nonnormal data between 2 or more groups. The significance was evaluated at $\mathrm{p}<0.05$ level.

\section{RESULTS}

A total of 155 men (51.7\%) and 145 women (48.3\%) participated in the study. Of the patients included in the study, 159 (53\%) were between the ages of 18 and $38,95(31.7 \%)$ were between the ages of 39 and 59 , and $46(15.3 \%)$ were between the ages of 60 and 80 . It was determined that 68 participants $(22.7 \%)$ were elementary school graduates, 35 (11.7\%) were secondary school graduates, $82(27.3 \%)$ were high school graduates and $115(38.3 \%)$ were university graduates. There were 163 (54.3\%) married patients and, 132 (45.7\%) single patients. It was found that 63 patients (21\%) had COVID-19, 237 (79\%) did not have (Table 1).

The mean state anxiety score of the patients included in the study was found to be $43.38 \pm 8.34$. The relationship between the state anxiety score and the demographic data was examined. When the relation of state anxiety score according to age was evaluated, it was determined that there was no statistically significant difference among all age groups. Considering the mean state anxiety scores in terms of gender, the anxiety scores of women were higher, but there was no statistically significant difference between the genders. There was no statistically significant effect of marital status and educational status on the mean state anxiety score. Although the mean anxiety score of those who had COVID-19 was slightly higher, there was no statistically significant difference in terms of the state anxiety score between the patients who had COVID-19 and those who did not have (Table 2).

The frequency data of the answers given to the COVID-19 and patient-related questionnaire form, which constitutes the last part of the survey, are summarized in Table 3. Comparing the mean state anxiety score by patient-related questions, it was found that the mean state anxiety scores were statistically significantly different among the answers to the questions (Table 4). The anxiety score of those who think that COVID-19 can be transmitted through dental treatment was statistically significantly higher than those who think that otherwise $(\mathrm{p}<0.001)$. The scores of those who said no were found to be significantly lower than the hesitant $(p<0.041)$. The anxiety score of those who thought that adequate measures were taken in the dental unit was found to be significantly lower than those who said both no and hesitant $(\mathrm{p}<0.001, \mathrm{p}<0.001$, respectively). The anxiety score of those who found the measures
Table 1. Demographic features of the patients

\begin{tabular}{|lcc|} 
& \multicolumn{2}{c|}{ Descriptive features (n=300) } \\
\cline { 2 - 3 } & Mean \pm SD & Median (Min-Max) \\
\hline STAI(Anxiety) scores & $43.38 \pm 8.34$ & $44(20-76)$ \\
Age & $\mathbf{n}$ & $\%$ \\
$18-38$ & 159 & 53.0 \\
$39-59$ & 95 & 31.7 \\
$60-80$ & 46 & 15.3 \\
Gender & & \\
Female & 145 & 48.3 \\
Male & 155 & 51.7 \\
Education & & \\
Elemantary school & 68 & 22.7 \\
Secondary school & 35 & 11.7 \\
High school & 82 & 27.3 \\
University+Graduate degree & 115 & 38.3 \\
Marital status & & \\
Married & 163 & 54.3 \\
Single & 137 & 45.7 \\
Had COVID-19 infection & & \\
Yes & 63 & 21.0 \\
No & 237 & 79.0 \\
\hline & & \\
\hline & & \\
\hline
\end{tabular}

Table 2. Associating the STAI scale scores with the demographic features

\begin{tabular}{|lccc|}
\hline Variables & n & Mean \pm SD & p \\
\hline Age & & & 0.318 \\
$18-33$ & 159 & $43.08 \pm 8.61$ & \\
$39-59$ & 95 & $43.96 \pm 8.44$ & \\
$60-80$ & 46 & $43.26 \pm 7.18$ & \\
Gender & & & 0.083 \\
$\quad$ Female & 145 & $44.54 \pm 7.64$ & \\
$\quad$ Male & 155 & $42.3 \pm 8.82$ & \\
Education & & & 0.897 \\
$\quad$ Elemantary school & 68 & $43.57 \pm 7.72$ & \\
Secondary school & 35 & $42.86 \pm 9.16$ & \\
High school & 82 & $43.5 \pm 7.89$ & \\
University+Post graduate & 115 & $43.35 \pm 8.82$ & \\
Marital status & & & 0.258 \\
$\quad$ Married & 163 & $43.72 \pm 8.67$ & \\
Single & 137 & $42.99 \pm 7.94$ & \\
Had COVID-19 infection & & & 0.118 \\
$\quad$ No & 237 & $43.12 \pm 8.35$ & \\
Yes & 63 & $44.37 \pm 8.29$ & \\
\hline * Significant at 0.05 level; Mann Whitney U test for 2 groups, \\
Kruskal Wallis test for 3 or more groups
\end{tabular}

taken by dentists sufficient while treating the patient was found to be statistically significantly lower than those who found insufficient and hesitant $(\mathrm{p}<0.001)$. The anxiety score of the patient who said no to the question of whether they would seek dental treatment if their condition was not urgent was found to be statistically significantly higher than those who said yes $(p<0.003)$. The anxiety score of those who said yes to the question of whether they think dentist clinics have a high risk of contamination was found to be statistically 
significantly higher than those who said no $(\mathrm{p}<0.011)$. The anxiety score of the patients who thought that the dentist can transmit COVID-19 during dental treatment was found to be statistically significantly higher than those who thought otherwise $(\mathrm{p}<0.013)$. The anxiety score of those who said yes to the question of whether they think they could be infected with COVID-19 from the other patients in the waiting area was statistically significantly higher than those who said no $(\mathrm{p}<0.010)$. The anxiety score of those who said yes to the question of whether they feel safe because healthcare professionals received the COVID-19 vaccine was found to be statistically significantly lower than those who said no $(\mathrm{p}<0.004)$. There was no statistically significant difference between the anxiety scores of those who said yes, no and hesitant to the question of whether they would like to be vaccinated if they have the option.

The anxiety score of those who said yes to the question of whether they would have had your dental treatment safely if vaccinated, was found to be statistically significantly lower than those who said both no and hesitant $(\mathrm{p}<0.001$, $\mathrm{p}<0.003$, respectively).

\begin{tabular}{|c|c|c|c|}
\hline & & $\mathbf{n}$ & $\%$ \\
\hline \multirow{3}{*}{$\begin{array}{l}\text { 1-Do you think COVID-19 } \\
\text { can be transmitted by receiving } \\
\text { dental treatment? }\end{array}$} & Yes & 127 & 42.3 \\
\hline & No & 107 & 35.7 \\
\hline & Hesitant & 66 & 22.0 \\
\hline \multirow{3}{*}{$\begin{array}{l}\text { 2-Do you think that adequate } \\
\text { measures are taken in the } \\
\text { unit you apply for a dental } \\
\text { treatment? }\end{array}$} & Yes & 246 & 82.0 \\
\hline & No & 25 & 8.3 \\
\hline & Hesitant & 29 & 9.7 \\
\hline \multirow{3}{*}{$\begin{array}{l}\text { 3-Do you find the measures } \\
\text { taken by dentists sufficient? } \\
\text { (Disposable gowns, masks, } \\
\text { visors, caps, etc.) }\end{array}$} & Yes & 268 & 89.3 \\
\hline & No & 14 & 4.7 \\
\hline & Hesitant & 18 & 6.0 \\
\hline \multirow{3}{*}{$\begin{array}{l}\text { 4-If your situation was not } \\
\text { urgent, would you apply for } \\
\text { dental treatment? }\end{array}$} & Yes & 75 & 25.0 \\
\hline & No & 192 & 64.0 \\
\hline & Hesitant & 33 & 11.0 \\
\hline \multirow{3}{*}{$\begin{array}{l}\text { 5-Do you think dental } \\
\text { clinics have a high risk of } \\
\text { contamination? }\end{array}$} & Yes & 133 & 44.3 \\
\hline & No & 109 & 36.3 \\
\hline & Hesitant & 58 & 19.3 \\
\hline \multirow{3}{*}{$\begin{array}{l}\text { 6-Do you think you can get } \\
\text { COVID-19 from your dentist } \\
\text { during dental treatment? }\end{array}$} & Yes & 94 & 31.3 \\
\hline & No & 156 & 52.0 \\
\hline & Hesitant & 50 & 16.7 \\
\hline \multirow{3}{*}{$\begin{array}{l}7 \text {-Do you think you can get } \\
\text { COVID-19 from other patients } \\
\text { in the waiting room? }\end{array}$} & Yes & 178 & 59.3 \\
\hline & No & 78 & 26.0 \\
\hline & Hesitant & 44 & 14.7 \\
\hline \multirow{3}{*}{$\begin{array}{l}8 \text {-Do you feel safe because } \\
\text { healthcare professionals receive } \\
\text { COVID-19 vaccine? }\end{array}$} & Yes & 206 & 68.7 \\
\hline & No & 51 & 17.0 \\
\hline & Hesitant & 43 & 14.3 \\
\hline \multirow{3}{*}{$\begin{array}{l}\text { 9-If you have the option of } \\
\text { vaccination, would you like to } \\
\text { have it? }\end{array}$} & Yes & 202 & 67.3 \\
\hline & No & 61 & 20.3 \\
\hline & Hesitant & 37 & 12.3 \\
\hline \multirow{3}{*}{$\begin{array}{l}\text { 10-If you were vaccinated, } \\
\text { would you have your dental } \\
\text { treatment safely? }\end{array}$} & Yes & 204 & 68.0 \\
\hline & No & 40 & 13.3 \\
\hline & Hesitant & 56 & 18.7 \\
\hline
\end{tabular}

\section{DISCUSSION}

The rapid spread of COVID-19 around the world has caused significant healthcare problems. In addition to the fact that the pandemic process physically affects people, many psychological problems have also occurred. It has traumatic effect on humans and causes their anxiety levels to increase (7). Especially during the dental treatment, it has been reported that there is a serious risk of contamination for dentists, dental staff and patients $(1,8,9)$. Therefore, the purpose of this study is to evaluate the dental anxiety level of patients during the COVID-19 pandemic process and to obtain information about the level of awareness, perceptions and attitudes of patients seeking dental treatment.

\begin{tabular}{|c|c|c|c|}
\hline Questions & n & Mean \pm SD & p \\
\hline QUESTION 1 & & & $0.001^{*}$ \\
\hline Yes & 127 & $45.35 \pm 7.11$ & \\
\hline No & 107 & $40.97 \pm 8.93$ & \\
\hline Hesitant & 66 & $43.5 \pm 8.63$ & \\
\hline QUESTION 2 & & & $0.001^{*}$ \\
\hline Yes & 246 & $42.35 \pm 8.17$ & \\
\hline No & 25 & $48.76 \pm 8.89$ & \\
\hline Hesitant & 29 & $47.55 \pm 6.05$ & \\
\hline QUESTION 3 & & & $0.001^{*}$ \\
\hline Yes & 268 & $42.73 \pm 8.13$ & \\
\hline No & 14 & $48.07 \pm 10.75$ & \\
\hline Hesitant & 18 & $49.5 \pm 5.54$ & \\
\hline QUESTION 4 & & & $0.007^{*}$ \\
\hline Yes & 75 & $40.57 \pm 9.36$ & \\
\hline No & 192 & $44.69 \pm 7.54$ & \\
\hline Hesitant & 33 & $42.15 \pm 8.79$ & \\
\hline QUESTION 5 & & & $0.034^{*}$ \\
\hline Yes & 133 & $45.05 \pm 7.27$ & \\
\hline No & 109 & $41.51 \pm 9.13$ & \\
\hline Hesitant & 58 & $43.07 \pm 8.43$ & \\
\hline QUESTION 6 & & & $0.039^{*}$ \\
\hline Yes & 94 & $45.19 \pm 6.88$ & \\
\hline No & 156 & $42.19 \pm 8.98$ & \\
\hline Hesitant & 50 & $43.7 \pm 8.26$ & \\
\hline QUESTION 7 & & & $0.019^{*}$ \\
\hline Yes & 178 & $44.72 \pm 7.44$ & \\
\hline No & 78 & $41.42 \pm 8.98$ & \\
\hline Hesitant & 44 & $41.43 \pm 9.63$ & \\
\hline QUESTION 8 & & & $0.012^{*}$ \\
\hline Yes & 206 & $42.41 \pm 8.68$ & \\
\hline No & 51 & $46.22 \pm 8.14$ & \\
\hline Hesitant & 43 & $44.67 \pm 5.69$ & \\
\hline QUESTION 9 & & & 0.129 \\
\hline Yes & 202 & $43.29 \pm 8.57$ & \\
\hline No & 61 & $42.39 \pm 7.93$ & \\
\hline Hesitant & 37 & $45.54 \pm 7.51$ & \\
\hline QUESTION 10 & & & $0.001^{*}$ \\
\hline Yes & 204 & $42.11 \pm 8.51$ & \\
\hline No & 40 & $46.55 \pm 8.41$ & \\
\hline Hesitant & 56 & $45.75 \pm 6.43$ & \\
\hline
\end{tabular}


When the results obtained in the study were examined, no difference was detected between the sociodemographic data of the individuals and their state anxiety scores. In many studies, it has been found that women perceive the disease as more contagious and lethal, and experience higher levels of anxiety $(10,11)$. Also the studies conducted during the COVID 19 pandemic revealed that women experience higher levels of anxiety than men $(12,13)$. In the present study, no difference was determined in terms of anxiety levels between men and women. These results are similar to the result of a study reporting that women and men were psychologically affected by the pandemic at the same level of stress and anxiety (14).

In the present study, no statistically significant difference was found between the state anxiety level scores according to the age variable. Similar to our results, a previous study indicated that there was no statistically significant difference between the state anxiety level scores and age variable, however, it was reported that there was a statistically significant difference in the trait anxiety level scores according to the age variable (13). There are many studies reporting that anxiety level is not affected by age $(15,16)$. However, it has been determined that the anxiety levels of young people were higher in studies conducted during the COVID-19 pandemic process $(17,18,19)$. It was found in the study that the anxiety score of those who had COVID 19 was higher. Given the difficulties experienced by individuals with the disease, it is considered normal to have higher levels of anxiety. Shevlin et al. (17) stated that being married and having children increased the stress level during the COVID-19 pandemic. However, in the present study, no significant difference was detected between married and single participants in terms of the mean state anxiety scores.

The data we obtained in the study revealed that the majority of individuals think that they can be infected with COVID- 19 by receiving dental treatment. Sahin et al. (20) reported similar results in their study. In addition, in the present study and other studies, it has been indicated that patients would consult a dentist in only emergency cases during the pandemic process (21). Therefore, the precautions taken in dental clinics are very important in terms of patients' perspective on dental treatment. During the pandemic process, in dental clinics; the importance given to personal protective equipment has been increased, the use of equipment such as disposable protective clothing, disposable cap, protective glasses, face shield, N95 mask has been increased. Disinfection points have been created in common areas for hand hygiene, essential measures have been taken for maintaining social distance, and in particular, dentistry applications causing aerosol formation have been provided in rooms that are adequately ventilated with natural air flow. In the present study, the majority of patients thought that the precautions taken in dental clinics were sufficient, and when the anxiety score of the individuals was evaluated, it was observed that the anxiety scores of those who thought that adequate precautions were taken were lower.

It was found in the study that the number of people who thought that they can get COVID-19 from the dentist during dental treatment was less than those who thought that they would not be infected. On the other hand, the number of those who thought that other patients can transmit COVID-19 in the waiting area was more than those who thought otherwise. Similar to these results, Moffat et al. reported that the greatest risk related to dental care in terms of COVID-19 was to contract the disease from other patients in the dental office (22). These data indicate that the precautions taken by dentists while treating patients instill confidence in patients.

At the time of this study, almost all healthcare professionals were vaccinated against COVID-19, but the majority of patients had not yet been vaccinated. As a result of the survey, it could be said that the vast majority of patients feel safe because healthcare professionals have been vaccinated. At the same time, the majority of patients stated that if there was an option, they would want to be vaccinated. In addition, according to the results of the study, the number of people who think that they can receive dental treatment safely if they are vaccinated is quite high.

\section{CONCLUSION}

It has been observed that the anxiety level of patients who applied to dental clinics for dental treatment have increased during the COVID-19 pandemic process. However, the measures taken in this process increase confidence in the patients. The present study demonstrated that patients were aware of the recommendations related to COVID-19 disease and the importance of being vaccinated and concluded that being vaccinated reduce the anxiety level of people. It is recommended to carry out similar studies on larger populations to obtain comprehensive and comparable data.

\section{ETHICAL DECLARATIONS}

Ethics Committee Approval: The survey was approved by the Gaziantep University Clinical Researchs Ethics Committee (Date: 10.03.2021, Decision No: 2021/68).

Informed Consent: All patients signed the free and informed consent form.

Referee Evaluation Process: Externally peer-reviewed. 
Conflict of Interest Statement: The authors have no conflicts of interest to declare.

Financial Disclosure: The authors declared that this study has received no financial support.

Author Contributions: All of the authors declare that they have all participated in the design, execution, and analysis of the paper, and that they have approved the final version.

\section{REFERENCES}

1. Peker İ, Pamukçu U, Taka K, Üçok Ö. Diş hekimliği pratiğinde Koronavirüs salgınına karşı alınması gereken önlemler. Turkiye Klinikleri J Dental Sci 2021; 27: 294-306

2. Meng L, Hua F, Bian Z. Coronavirus disease 2019 (COVID-19): Emerging and future challenges for dental and oral medicine. J Dent Res 2020; 99: 481-7.

3. Khader Y, Al Nsour M, Al-Batayneh OB, et al. Dentists' awareness, perception, and attitude regarding COVID-19 and infection control: cross-sectional study among Jordanian dentists. JMIR Public Health Surveill 2020; 6: e18798.

4. Rubin JG, Slovin M, Krochak M. The Psychodynamics of Dental Anxiety and Dental Phobia. Dental Clin North Am 1988; 32 647-56.

5. Spielbergerr CD, Goursuch RL, Lushene RE. Manuel for the State-Trait Anxiety Invertory. California: Consulting Psychologists Press.1970.

6. Öner N, Le Compte A. Durumluk ve Sürekli Kaygı Envanteri El Kitabı. 2. Baskı. İstanbul Boğaziçi Üniversitesi Yayınları. 1998.

7. Joos, A. Psychosomatic medicine and COVID-19 pandemic. Psychotherapy and Psychosomatics 2020; 89: 263-64.

8. Zou X, Chen K, Zou J, Han P, Hao J, Han Z. Single-cell RNAseq data analysis on the receptor ACE 2 expression reveals the potential risk of different human organs vulnerable to 2019 nCoV infection. Front Med 2020; 14: 185-92.

9. Coulthard P. Dentistry and coronavirus (COVID-19) - moral decision-making. Br Dent J 2020; 228: 503-5.

10.Lau JTF, Yang X, Pang E, Tsui HY, Wong E, Wing YK. SARSrelated perceptions in Hong Kong. Emerg Infect Dis 2005; 11: 417-24.

11. Çırakoğlu OC. Domuz gribi (H1N1) salgını ile ilgili algıların, kayg1 ve kaçınma düzeyi değişkenleri bağlamında incelenmesi. Türk Psikoloji Bülteni 2011; 26: 48-64.

12. Wang C, Pan R, Wan X, et al. Immediate psychological responses and associated factors during the initial stage of the 2019 coronavirus disease (COVID-19) epidemic among the general population in china. Environment Res Public Health 2020; 17: 1729.

13.Göksu Ö, Kumcağız H. COVID-19 salgınında bireylerde algılanan stres düzeyi ve kaygı düzeyleri. Turk Stud 2020; 15: 463-79.

14.Zhang W, Wang K, Yin L, et al. Mental health and psychosocial problems of medical health workers during the COVID-19 epidemic in china. Psychother Psychosom 2020; 89: 242-50.

15.Erdur B, Ergin A, Turkcuer I, Parlak I, Ergin N, Boz B. A study of depression and anxiety among doctors working in emergency units in Denizli, Turkey. Emerg Med J 2006; 23: 759-63.

16.Kutanis RU, Tunç T. Hemşirelerde benlik saygısı ile durumluk ve sürekli kaygı arasındaki ilişki: Bir üniversite hastanesi örneği. "İş, güç". Endüstri İlişskileri ve İnsan Kaynakları Derg 2013; 15: $1-15$.

17.Shevlin M, McBride O, Murphy J, et al . Anxiety, depression, traumatic stress, and COVID-19 related anxiety in the ukgeneral population during the COVID-19 pandemic. UK population mental health and COVID-19. BJPsych Open 2020; 6: 1-25.
18.Bohlken J, Schömig F, Lemke MR, Pumberger M, Heller SG. COVID-19 pandemic: Stress experience of healthcare workersA short current review Psychiatr Prax 2020; 47: 190-7.

19.Joos A. Psychosomatic medicine and COVID-19 pandemic. Psychother Psychosom 2020; 89: 263-4.

20.Sahin O, Sahin SC. Türkiye'de COVID-19 normalleşme sürecinde hastaların dental tedavilere bakış açısının ve kurum tercihlerinin incelenmesi. Ankara Med J 2020; 4: 869-81.

21.Ovalığlu Z, Bozkurt DA, Akman M. COVID-19 pandemi sürecinde endodonti kliniğine gelen hasta anksiyete düzeyi. NEU Dent J 2020; 2: 98-102.

22.Moffat RC, Yentes CT, Crookston BT, West JH. Patient Perceptions about Professional Dental Services during the COVID-19 Pandemic. JDR Clin Trans Res 2021; 6: 15-23. 